\title{
The sustainability of human resource planning for construction projects
}

\author{
Adegbenga Raphael Ashiru ${ }^{1}$ and Adebimpe Lucia Ashiru ${ }^{2}$ \\ ${ }^{1}$ Lecturer- Department Of Building Technology, Federal Polytechnic, Kaura - Namoda. Zamfara - State. Nigeria \\ ${ }^{2}$ Lecturer- Department Of Business Administration and Management, Federal Polytechnic, Kaura - Namoda. Zamfara - \\ State. Nigeria
}

\begin{abstract}
Human Resource planning for construction project is described as a way of managing human resources within a growing nature of construction industry. Nonetheless, management of human resource is an extremely stimulating task. However, in spite of the substantial resources allocated to construction planning, there are rising concerns over its failure to achieve its goals and different application of planning strategies. It is against this backdrop that this research was carried out to examine the sustainability of Human resource planning for construction projects to justify the aforesaid statement. Furthermore, the researchers adopted a quantitative approach that provided a broader understanding of the research. SPSS Version 20 was used to obtain the descriptive and inference statistical analysis. Interestingly, majority of the literature findings were justified by the empirical findings noting that there is correlation between the two findings except where the respondent chose combination of the causes of neglect of HR planning on construction projects stressing that one cause cannot significantly neglect the process on construction projects. Conclusively, the research results indicated that through improving the practicality of Project HR planning by construction organisations, it would contribute significantly towards improving performance both at organisational and project level. The findings recommended guidelines for improving the visibility and adaptability of sustainable HR planning for construction projects and further provided justification for implementing its policies and procedures.
\end{abstract}

\section{Introduction}

The word planning is defined as a detailed system for achieving an objective meaning. However, a detailed system includes the method, the activities to carryout, time of those activities and resources including finance [1]. Moreover, an organisational planning creates efficiency and effectiveness in an organisation. Its provides clearer focus which bonds managers and subordinates in creating strong teams and produces limitless fulfillment among planners with common vision. Nonetheless, effective planning before implementation is significant for successful delivery of every project but there are indications of inadequate effort and time in planning construction projects especially at tender and pre-contract stages [2].

Furthermore, in spite of the substantial resources allocated to construction planning, there are rising concerns over its failure to achieve its goals and the different application of planning strategies [3]. Nevertheless, the significant factor in implementing organisation's planning policy in construction is the need of each employee performance measurement through effective training [4]. A system that measures performance is needed in order to monitor improvements within construction teams [5]. Also, Langford et al argued that construction industry has a habit to shed personnel as part of a survival plan, retraining those whose skills are replaceable [6]. To justify the aforesaid statement, the research aimed to examine and promote the sustainability of HR planning for construction projects and to achieve this, the under listed objectives are set to achieve the aim of the research:

- To critically review literature relating to challenges of HR planning for construction projects and develop proper understanding of current situation in Construction industry;

- To collect data from contracting organisations including Wolverhampton city council on challenges of $\mathrm{HR}$ planning for construction projects;

- To analyse data collected and validate a framework that could help stakeholders focuses their priorities

\footnotetext{
${ }^{*}$ Corresponding Author: ashiruadegbenga@fedponam.ed.ng
} 
of sustainable HR planning for construction projects.

- To draw conclusions on the relevance of sustainable HR planning for construction projects and makes recommendations to practitioners and for future research.

As human resource (HR) is significant to all industries, including the construction industry, maintaining and attracting skilled employees is a priority. Hence, complexities in human contacts within construction industry will bring about construction-based issues of HR planning in such organisations [7]. However, it is against this backdrop that this research was carried out to answer the following fundamental research questions:

- What is the relationship between HR planning and construction project productivity;

- How can sustainable Human Resource planning be used to improve individual and team performance at both construction organisation and project levels

To ease the problem which underperformance have placed on construction industry, therefore, researcher will discuss basic ways in which HR planning could be used to manage construction projects to justify Loosemore's opinion that team or individual behavior have posed a rising concern on risks in construction projects and recommended that effective human resource planning is the possible way to alleviate those construction risks [8].

\section{General Overview of Construction Industry}

Construction industry offers opportunity to mankind through job creation and the industry offers substantial responsibilities for those who work in it [9]. Nonetheless, the industry creates built environment as it designs, produce, conserve and demolishes structures [10]. A main contractor (Builder) tenders for construction contracts and when contract is awarded, the Builder further award subcontract to specialised contractors. Furthermore, micro organisations dominates construction sector with various organisation merging together to form teams to carry-out a project [11]. Those involved in project delivery include professionals such as clients/owner and general contractor, suppliers and subcontractors forms a team of contractor. Also, Architects, Civil Mechanical, Structural, Electrical Engineers, Land and Quantity Surveyors forms Consultant's team [12]. However, construction industry remains a poorly understood sector despite its contribution to economic and social growth of nations [11]. Finally, the agenda of performance improvement has not been discharging by management of workforce within the sector.

\subsection{Human Resource Planning in Construction}

A process that ascertains current and future organisational human resources needs to achieve organisational goals is described as Human Resource
Planning. However, HR planning should be the link between HRM and the overall organisational strategic plan. Nevertheless, Bulla and Scott argued that HR planning is the process of acknowledging organisational HR requirements and plans to satisfy those requirements are made [13]. Furthermore, Reilly maintained that HR planning is a way that an organization estimates the demand for workforce and evaluates its nature, size and sources of supply to meet the demand [14]. HR planning further includes creation of strategies in recruitment and selection, retention, talent management, absence management, flexibility and employer brand.

Nonetheless, construction firms must ensure that current and future market analysis are carried out to meet functions of HR planning thereby ensuring that right percentage of individuals with right skill are considered [15]. By analysing the current human resources as well as linking these to potential opportunities in future market may allow recruitment and employeedevelopment plans decisions to be made [16]. Subsequently, Leng suggested HR planning approaches that could use to ease HR problems as follows [15];

\subsubsection{Evaluation of Current Resources}

Evaluation current human resource is another stage in HR planning through assessing employee's interest, abilities, skills and experiences. After comparing these with SHRM plans, resource shortage that required filling of skills gaps will be outlined [17]. Through this, efficient database must be created to accommodate information about employees' qualification, interests, training and experience during employment lifespan.

\subsubsection{Job Analysis and Design}

Job analysis is a process of analysing organisational restructuring methods to meet current and future business needs through collection of information of existing human resource and this further includes the following:

- Assigning individual responsibilities to future needs by examining the organisational structure;

- Identifying shortages or misfits;

- Redesigning misfit positions and individuals responsibilities to suit the firm's future needs.

\subsubsection{Internal Availability Analysis}

Before carrying out external recruitment, the organisation may check the availability of existing employee through employee future movement analysis in relation to transfers, promotions, resignations, terminations and retirements. However, organisations can predict these trends to prevent temporary shortage of employee [18]. An organisation could compare internal resources availability with the future needs through HR approach. Through this, internal employee-development and external recruitment could be determined. 


\subsubsection{Employee Turnover Analysis}

Employee turnover analysis can be carried out for two purposes, namely; to ascertain possible future employee replacement and identify purpose for employee transient and best action to retain them. In fact, an assessment could be carried out on the effect of promoting and transferring of individuals in an organisation through HR planning [19].

\subsection{Application of Sustainable Human Resource Planning For Construction Projects}

For efficiency, effectiveness and upward growth in an organisation, there must be agreed objectives to be able to manage risks with establishment of goals and targets through organisational strategic level [6]. Apparently, the effective use of individuals involved in the project is the essence of project HRM. This revolves round identifying, assigning project responsibilities, documenting and reporting relationship. Although, necessity for planning is very vital in construction due to;

- project complexity which requires a huge number of human input;

- The overall competitive approach in an unstable market and aggressive environment.

Therefore, project HR manager must possessed wide knowledge about market, product and method the organisation is operating. This will allow project work analysis and labour requirement be carried out. However, Leng identified in Table 1, a synopsis of project HR planning as follows [15]:

Table 1- Overview of Project HR Planning

\begin{tabular}{|l|l|l|}
\hline INPUT & \multicolumn{1}{|c|}{ TOOLS \& } \\
TECHNIQUES & \multicolumn{1}{|c|}{ OUTPUT } \\
\hline $\begin{array}{l}\text { Interfaces in the } \\
\text { project }\end{array}$ & $\begin{array}{l}\text { Project } \\
\text { Templates }\end{array}$ & $\begin{array}{l}\text { Roles and } \\
\text { responsibility }\end{array}$ \\
\hline $\begin{array}{l}\text { Labour } \\
\text { Requirement }\end{array}$ & $\begin{array}{l}\text { Human resource } \\
\text { procedures \& } \\
\text { practices }\end{array}$ & $\begin{array}{l}\text { Labour } \\
\text { management plan }\end{array}$ \\
\hline $\begin{array}{l}\text { Organisational } \\
\text { Constraints }\end{array}$ & $\begin{array}{l}\text { Analysis of } \\
\text { stakeholder }\end{array}$ & $\begin{array}{l}\text { Organisational } \\
\text { chart and } \\
\text { Supporting } \\
\text { Documents }\end{array}$ \\
\hline
\end{tabular}

A) Inputs to Project Human Resource Planning

\section{(I) Interfaces in the project}

- Organisational interfaces- Organisational interfaces can be formal or informal relationships between departments and could be extremely complex or simple. Example could be an emergence compound telecommunications system to coordinate different subcontractors on a project.
- Technical interfaces- Technical interfaces could be formal or informal relationship between professionals on a project and this happen within project phases where civil engineer work could be compatible with design of structural engineer.

- Interpersonal interfaces - this could be formal or informal relationships between various individuals on a site.

(II) Labour requirement- This required individual or team competencies at different time frame. General resource requirements may involve labour requirement which form part of resource planning.

\section{(III) Organisational Constraints}

- Collective bargaining- prescribed agreements with labour union may require assured responsibilities or relationships;

- Project Team Preferences- Success of a team in previous project can probably be recommended for similar project in future.

\section{B) Techniques And Tools For Project Organisational Human Resource Planning}

- Project Templates- Since every project is distinctive, definitions of responsibility of a comparable project can help hasten the process of organisational planning in a new project.

- Human resource procedures and practices Many organisations operates different guidelines, policies and procedure with series of facets of organisational planning that can support project team. Example is where organisations allow a manager to perform his duties like a coach.

- Analysis of Stakeholder- The needs of stakeholders should be identified, analysed and met.

C) Outputs from the project organisational human resource planning

(I) Roles and Responsibility - This is about who does what and who decides what. This should be allocated to suitable project professional. Most roles and responsibilities may vary over time and allocated to active professionals involved in project activities.

(II) Labour Management Plan - It described project team take off time and defines when and how labour will be utilised. The labour plan could be very detailed and be formal or informal which is subjected to project requirements. 
(III) Organisational chart- This is a project reporting relationships in graphical representation. An organisational chart is a typical example of organisational breakdown structure (OBS) which could be formal or informal and detailed framed that shows departments in an organisation and their responsibilities depending on project necessities.

(IV) Supporting document - Organisational planning supporting detail is subjected to project size and area. Supporting detail information may include the following,

- Job descriptions- an outlines of job title, responsibilities, Skills, authority, physical environment, and other requirements to execute a job.

- Training needs- an employee skill is very important on a project and those skills could be developed as part of the project.

However, the nature of work, organisation strategy, economic and social changes are vital HR planning factors influencing for labour force supply in construction industry and it is very vital for the management of the organisation to ensure the effective use of HR planning and avoid inconsistency so that it can bring coherence and compatibility between project team members as well as the different group within the structure of the firm [20].

\subsection{Impacts of Sustainable HR Planning on Performance for Construction Projects}

- Enhance Technical Performance- To achieve technical performance of a project, technical requirements must be specified at the commencement of the project in order to eliminate human error, possible delay and low skill level.

- Increases Technical Innovations- Effective ways of identifying technical problems during the project with ability of solving them. Such innovation includes ways of enhancing critical thinking and problem solving abilities.

- Improves Effectiveness In execution Of ProjectThis is an effective way of meeting time and cost targets. This involves achieving quality standard, time and cost targets.

- Increases Personal Growth- Project team commitment towards professional development and challenges;

- Boost Business Performance- Ability of business activities to perform through achieving low operational control, employee turnover and repetitive business.

\subsection{Causes of Failure in HR Planning for Construction Projects}

Causes of failure in Project HR Planning are highlighted by [15] as follows:
- Poor management and leadership commitment

- Poor organisation's management support;

- Poor commitment of stakeholders concerning HR practices

- Resistance to change in new HR techniques and tools

- Neglect of significance of HR involvement in a project

\section{Methodology}

This research was carried out in Wolverhampton West Midlands, United Kingdom to identify the various impacts of sustainability of Human Resource planning on construction projects in Wolverhampton city. Nonetheless, non-probability sampling was adopted as this enables us to select participants based on the research area in Wolverhampton city. This further assumed a purposive sampling strategy where respondents were selected at the discretion of the researcher but with the sole purpose to be typical of the whole population and the research question will be best examined to evaluate respondent engagement. The researcher adopted a quantitative approach that provided a broader understanding of the research problem [20] and [21]. SPSS Version 20 was used to obtain and analyse the descriptive and inference statistical analysis.

The researcher distributed twenty (20) wellstructured questionnaires to selected respondents who are managers involved in decision making at strategic level for their respective organisations [6]. The researcher recovered twelve (12) responses achieving $60 \%$ of the feedback. The data collected was analysed by descriptive and inference statistics. The research instrument also measures a reliability and validity test of 0.766. Furthermore, data relating to challenges of HR planning were extracted from four questions which were adopted from [15] to develop varying challenges of HR planning for the research work. Indeed, the paper presented various improvement methods that can be adopted to encourage the practicality of the subject matter as SPSS levene test was used to ascertain the equality of variance for the research work.

\section{Findings}

The literature sources agreed to varying challenges of HR planning on construction projects. The four identified factors considered are presented in table 2, 3, 4 and 5 .

Table 2. Factors HR Planning

\begin{tabular}{|l|l|l|}
\hline $\begin{array}{l}\text { Factors to look into when performing } \\
\text { HR planning operation for construction } \\
\text { projects }\end{array}$ & Mean & $\begin{array}{l}\text { Std. } \\
\text { Deviation }\end{array}$ \\
\hline $\begin{array}{l}\text { Does your organisation appraise labour } \\
\text { resources such as interest, abilities, skills } \\
\text { and experience? }\end{array}$ & 3.99 & 1.187 \\
\hline $\begin{array}{l}\text { Does your organisation designs job } \\
\text { specifications to make sure right } \\
\text { individuals are in right positions }\end{array}$ & 3.76 & 1.404 \\
\hline
\end{tabular}

Source: Field Survey, 2017 
The empirical result indicated that most of the respondents Strongly Agree that evaluation the current and existing resources is paramount important for their organisation where individual interest, abilities, skills, or experience in HR Planning could be carried out before beginning of any construction projects with table 2 reflecting opinion with the mean 3.99. Also, job specification as a major factor is considered at an Agreeable rate. This indicated that efficient design of job specifications could make responsibilities be allocated right individuals reflecting a mean of 3.76. Therefore, the literatures justified empirical result.

Table 3. Techniques and Tools in HR Planning

\begin{tabular}{|l|l|l|}
\hline $\begin{array}{l}\text { Application of techniques and tools in HR } \\
\text { planning }\end{array}$ & Mean & $\begin{array}{l}\text { Std. } \\
\text { Deviation }\end{array}$ \\
\hline $\begin{array}{l}\text { Does your organisation practices HR } \\
\text { procedures and guidelines in retaining } \\
\text { project teams }\end{array}$ & 3.53 & 1.605 \\
\hline $\begin{array}{l}\text { Does your organisation enhance labour } \\
\text { management plan to reduce cost and } \\
\text { increase motivation }\end{array}$ & 3.71 & 1.456 \\
\hline
\end{tabular}

Source: Field Survey, 2017

Analysis of table 3 shows that respondents strongly agreed that organisation set standard practices for HR procedures in allocating team responsibilities and producing guidelines for job activities reflecting mean of 3.53. This shows that job guidelines ought to obviously outline the work scope, job function, what to be carried out with essential skills and capabilities required from project team to successfully carryout the construction project. Eventually, the scale with mean 3.71 shows a strong positive approach practices when an organisation utilise standard HR procedures and guidelines and the feedback from labour management plan shows that respondents justified the literature that organisation should look into a suitable rewarding plan that would enhance level of employee's motivation and cost reduction to improve effectiveness.

Table 4. HR Planning on Performance

\begin{tabular}{|l|l|l|}
\hline $\begin{array}{l}\text { Effect of HR planning on performance } \\
\text { for construction projects }\end{array}$ & Mean & $\begin{array}{l}\text { Std. } \\
\text { Deviation }\end{array}$ \\
\hline $\begin{array}{l}\text { Does your organisation considers improving } \\
\text { team performance to improve efficiency on } \\
\text { the construction project through in } \\
\text { individual skills, competency and team } \\
\text { behaviour. }\end{array}$ & 3.08 & 1.569 \\
\hline $\begin{array}{l}\text { Does your organisation retrain project team } \\
\text { to enhance efficiency and performance }\end{array}$ & 3.18 & 1.368 \\
\hline $\begin{array}{l}\text { Does effective Project HR planning aids } \\
\text { technical innovation improvement and } \\
\text { efficient performance by eliminating delays, } \\
\text { labour error and upsurge manner of problem } \\
\text { solving }\end{array}$ & 3.69 & 1.625 \\
\hline Source: Finsurvey, 2017 & \\
\hline
\end{tabular}

Source: Field Survey, 2017

The observation of [23] argued that to improve efficiency and performance on construction projects, organisations need to place project team on formal training either on-job or off-job training. Nevertheless, the scenario as seen in table 4 having mean 3.08 and 3.18 specifies that formal developmental training of project team may improve efficiency and effectiveness of Human Resource. Nonetheless, on-job training offers a considerable benefit over off-job training in practice and widely practice by construction organisations.

Similarly, [23] opined that through effective HR technical innovation and performance could be improved to reduce human error, delays and enhance team problem solving skills. It is strongly agree that effective Project HR planning in practice will improve project deliveries to cost, time and standard quality through selection of right individuals for the right job reflecting mean 3.69. Continuous training of teams to enhance competencies will reduce chance of delay in project team task performance, human error and further improve problem solving abilities.

Table 5. Failure in HR Planning

\begin{tabular}{|l|l|l|}
\hline $\begin{array}{l}\text { Causes of failure } \\
\text { in HR planning for } \\
\text { construction }\end{array}$ & Mean & $\begin{array}{l}\text { Std. } \\
\text { Deviation }\end{array}$ \\
\hline A, B, C, D, E & 3.90 & 0.508 \\
\hline B,D & 3.09 & 1.023 \\
\hline B,E & 3.06 & 0.799 \\
\hline A,D & 3.07 & 1.995 \\
\hline A,C,D,E & 3.79 & 1.478 \\
\hline A,B,D & 3.57 & 1.282 \\
\hline B,D,E & 3.48 & 1.285 \\
\hline A,D,E & 3.18 & 1.240 \\
\hline A,E & 3.89 & 0.891 \\
\hline
\end{tabular}

Source: Field Survey, 2017

Identified failures are represented in table 5 with alphabet A-E and define as - A- Poor of effective management and leadership commitment; B- Poor organization's management support; C- Poor stakeholders commitment in regards to HR practices; DResistance to change in new HR techniques and tools; ENeglect of important of HR involvement in a project).

Nevertheless, the scales with mean $3.90 ; 3.09 ; 3.06$; $3.07 ; 3.79 ; 3.57 ; 3.48 ; 3.18$ and 3.89 shows that the entire occurrence have greater contribution to the neglect of important construction Project HR planning.

Table 6- Independent Sample t Test for Perceptions Factors in HR Planning

\begin{tabular}{|l|l|l|l|l|l|}
\hline \multicolumn{1}{|c|}{ Variables } & M & SD & T & df & $\begin{array}{l}\text { P- } \\
\text { VALUE }\end{array}$ \\
\hline $\begin{array}{l}\text { Does your } \\
\text { organisation } \\
\text { undertakes labour } \\
\text { resources such as } \\
\text { appraisals abilities, } \\
\text { interest, } \\
\text { skills or } \\
\text { experience. }\end{array}$ & & & & & \\
\hline Project managers & 1.80 & 0.76 & -3.21 & 24 & $0.004^{*}$ \\
\hline $\begin{array}{l}\text { Non Project } \\
\text { managers your }\end{array}$ & 3.10 & 1.37 & & & \\
\hline $\begin{array}{l}\text { Does job } \\
\text { organisation } \\
\text { design } \\
\text { specifications to } \\
\text { make sure that } \\
\text { responsibilities are } \\
\text { given to right } \\
\text { individuals. }\end{array}$ & & & & & \\
\hline Project managers & 1.70 & 0.66 & -2.096 & 5.765 & 0.087 \\
\hline $\begin{array}{l}\text { Non Project } \\
\text { managers }\end{array}$ & 2.69 & 1.26 & & & \\
\hline
\end{tabular}


Table 6 is the result of perception factors on Project Managers and Non-Project Managers. At 0.05 P-value, both Project managers and non- Project managers seems to strongly agreed on factors to look into when performing $\mathrm{HR}$ planning operation for construction projects such that their respective organisations create job specifications to ensure that right responsibilities are given to right individuals $(\mathrm{t}=-2.096, \mathrm{df}=5.765)$. On the other hand, non-Project managers hold stronger perception than Project managers for their respective organisations to undertake employee resources appraisals such as skills, abilities, experience and interests $(t=-3.21, \mathrm{df}=24)$. The implication of this is that non-Project managers agree more than Project managers that their respective organisations always undertake employee resources appraisals such as skills, abilities, experience and interests.

Table 7. Spearman's Rho Correlations Between Five Principal Causes of Neglect of HR Planning

\begin{tabular}{|l|l|l|l|l|l|}
\hline $\begin{array}{l}\text { HR Tools, } \\
\text { Techniques } \\
\text { And Output }\end{array}$ & $\begin{array}{l}\text { Poor } \\
\text { effective } \\
\text { management } \\
\text { and } \\
\text { leadership } \\
\text { commitment }\end{array}$ & $\begin{array}{l}\text { Poor } \\
\text { organisation' } \\
\text { s } \\
\text { management } \\
\text { Support }\end{array}$ & $\begin{array}{l}\text { Poor } \\
\text { stakeholde } \\
\text { rs } \\
\text { commitme } \\
\text { nt in } \\
\text { regards to } \\
\text { HR } \\
\text { practices }\end{array}$ & $\begin{array}{l}\text { Resistance } \\
\text { to change in } \\
\text { new HR } \\
\text { techniques } \\
\text { and tools }\end{array}$ & $\begin{array}{l}\text { Neglect of } \\
\text { important of } \\
\text { HR } \\
\text { involvement } \\
\text { in a project }\end{array}$ \\
\hline $\begin{array}{l}\text { Project } \\
\text { Templates }\end{array}$ & & & & & \\
\hline Correlation & 0.006 & 0.269 & 0.044 & -0.098 & -0.105 \\
\hline Sig $(p<0.05)$ & 0.976 & 0.169 & 0.848 & 0.634 & 0.616 \\
\hline $\begin{array}{l}\text { Analysis of } \\
\text { stakeholder }\end{array}$ & & & & & \\
\hline Correlation & -0.066 & -0.136 & 0.087 & 0.014 & 0.284 \\
\hline Sig $(p<0.05)$ & 0.742 & 0.500 & 0.682 & 0.938 & 0.157 \\
\hline $\begin{array}{l}\text { Human } \\
\text { resource } \\
\text { procedures } \\
\text { and practices }\end{array}$ & & & & & \\
\hline Correlation & 0.064 & 0.005 & 0.146 & $0.371\left(^{*}\right)$ & 0.273 \\
\hline Sig $(p<0.05)$ & 0.762 & 0.982 & 0.485 & 0.048 & 0.181 \\
\hline $\begin{array}{l}\text { Roles and } \\
\text { responsibility }\end{array}$ & & & & & \\
\hline Correlation & -0.312 & 0.026 & 0.334 & -0.124 & 0.032 \\
\hline Sig $(p<0.05)$ & 0.125 & 0.904 & 0.096 & 0.555 & 0.888 \\
\hline $\begin{array}{l}\text { Employee } \\
\text { management } \\
\text { plan }\end{array}$ & & & & & \\
\hline Correlation & -0.113 & 0.065 & 0.111 & 0.188 & 0.234 \\
\hline Sig $(p<0.05)$ & 0.579 & 0.757 & 0.584 & 0.379 & 0.247 \\
\hline & & & & & \\
\hline
\end{tabular}

Spearman's Rho correlation findings in Table 7 for five principal causes of HR planning neglect indicated that at 0.05 level of P-value the research shows that there is a strong correlation between resistance to change in new HR techniques and tools and Human resource procedures and practices (correlation $=0.371$ and $\mathrm{p}$ value $=0.048$ ) and was found to have better effect on site productivity since correlation significant is less than 0.05 . The implication of this correlation is that the more a project manager resists changing to adopt new HR techniques and tools, the more the neglect of human resource procedures and practices exist on construction project. Therefore, to achieve optimal productivity on construction project, it is advisable that an organisation allows the project manager to perform his responsibility as a coach to create a positive approach to people based management and avoid inconsistency so that HR planning for construction project can bring sustainable coherence and compatibility between project team members as well as the different group within the structure of the organisation. Lastly, transformational leadership from the organisation top management is necessary to help in creating a positive organisationalproject culture.

\section{Conclusion}

The strategic finding established factors to look into when performing HR planning operations for construction projects. Initially, effective utilisation of labour appraisals to assess interest, abilities, skills and experience and design job specifications to ensure the responsibilities are given to right individuals were identified in the literature review by different scholars as part of causes of desertion of HR planning on construction projects. However, the key consideration factors for Sustainable Project HR Planning (Organisation's structure with responsibilities given to right individuals and assessment of current resources) will bring about putting into practice of new HR Planning technique and tools for construction project. Essentially, the main reoccurring theme identified was that management of the construction organisations needs to look into the essential factors needed to be considered at the strategic level and the leaders leading a construction project team to consider those essential factors needed at operational level to clarify the numerous functions of HRM in the construction organisations and avoid inconsistencies among several practices on construction projects. Nevertheless, the impact of sustainable HR planning towards performance should include its efficient practices as advocated and strongly considered by both literature and empirical. Lastly, objectives of the paper were met as the sustainability of HR planning for construction projects were examined through literature review and substantiated with the responses from participant to obtain empirical findings which were justified in the research work.

\subsection{Recommendations}

Obviously, the paper findings suggested that the inconsistency in the various practices of HRM have led desertion of planning for construction project. Critically empirical findings results highlighted that construction industry recognised the use HR planning, therefore, adaptability and visibility of implementation of guidelines, policies and procedures of sustainable HR planning on construction project should be justified and improved. The following are recommended:

- Strategic plan should be incorporated into construction organisation system;

- HR planning objective should be incorporated into the construction organisational strategic plans; 
- Concerted efforts should be maintained by strategic decision makers in construction organisations to encourage contemplative learning and incessant improvements through training for individuals and teams;

- Sustainable application of HR technique and tools application should be encouraged to assess the need organisation and projects.

\subsection{Recommendations for Future Research}

The results from the research showed that it is preferable to explore all HR planning for construction project best practices and be adopted by construction organisations and leaders leading construction projects. However, further research can be carried out on implementation of Project HR Planning by stakeholders for its success.

\section{References}

1. A.R.J. Dainty, B.M. Bagilhole and R.H. Neale 'The Compatibility of Construction Companies' Human Resource Development Policies with Employee Career Expectations,' Engineering, Construction and Architectural Management 7, 169-78, (2000)

2. A. Nagendra, and M. Deshpande, Human Resource Information Systems (HRIS) in HR planning and development in mid to large sized organizations" Proceedia of Social and Behavioural Science, 133, 61-67 (2014)

3. C. Fogarassy, K. Szaboand, and J. Poor, Critical issues of human resource planning, performance evaluation and long-term development on the central region and non-central areas: Hungarian case study for investors. International Journal of Engineering Business Management 9, 1-9 (2017)

4. A. Laufer and R. Tucker, "Is Construction Planning Really Doing its Job? A Critical Examination of Focus, Role and Process" Construction Management and Economics, London, E. \& F. N. Spon, 5, 243-66 (1987)

5. L.Nesan, H. Jawahar and D. Gary. Empowerment in Construction: The way Forward for Performance Improvement, Baldock, Hertfordshine, England: Research Studies Ltd, (1999).

6. D. A. Langford R. Fellows, M. Hancock and A. Gale, Human Resource Management in Construction, $2^{\text {nd }}$ ed. London: Longman, (1995)
7. A. Dainty and M. Loosemore, Human Resource Management in Construction: Critical perspectives", London: Spon Press, (2012)

8. M. Loosemore, Construction Crisis Management, American Society of Civil Engineers, New York. (2000)

9. J. Schervayder and R.S. Mayo, Construction Fundamentals, $2^{\text {nd }}$ Ed. New Yoon: McGrew Hill. (2004)

10. L. J. Mullins, "Management and Organizational Behaviour", $5^{\text {th }}$ Edition, Essex: Pearson Education. (1999)

11. A. Dainty, I. Grugulis and D. Langford, Understanding Construction Employment: The Need for a Fresh Research Agenda Personnel Review. 36, 501-508 (2007)

12. G. Dessler, "Human Resource Management", 8th Ed. Upper Saddle River, New Jersey: Prentice Hall Incorporated. (2000)

13. D N. Bulla and P M. Scott, Manpower requirements forecasting: a case example, in Human Resource Forecasting and Modelling, $1^{\text {st }}$ Ed, Human Resource Planning Society: New York (1994)

14. P. Reilly, Guide to Workforce Planning in Local Authorities, Employers Organization for Local Government, London (2003).

15. T. H. Leng, Human resource planning and human resource development in construction. Master's Thesis, University Technology of Malaysia (2005)

16. P. Boxall and J. Purcell, Strategy and Human Resource Management, London: Palgrave Macmillan (2016)

17. K. Akingbola, "A Model Of Strategic Non-profit Human Resource Management." Voluntas: International Journal of Voluntary \& Non-profit Organizations 24, 214-240 (2013)

18. M. Loosemore, A. Dainty and H, Lingard, "Human Resource Management in Construction ProjectsStrategic and Operational Approaches", London: Spon Press (2003)

19. S.G. Naoum, Peoples and organisational management in construction: $1^{\text {st }}$ ed. London: Thomas Telford Publishing (2001)

20. P. Farrel, Writing a built environment dissertation. West Sussex, UK: Blackwell. 79. (2011).

21. S.G Naoum, Dissertation Research and Writing for Construction Students, $3^{\text {rd }}$ ed Abingdon, Oxon: Routledge. 67-97 (2013). 